\title{
Gliomatosis Cerebri Mimicking Encephalopathy in a Teenager Boy
}

\author{
Genç Bir Olguda Ensefalopatiyi Taklit Eden Gliomatozis Serebri
}

\section{Bilgen Isik ${ }^{1}$, Ummugulsum Gumus ${ }^{2}$, Alper Ozcan ${ }^{1}$, Ebru Yilmaz ${ }^{1}$, Fatma Turkan Mutlu ${ }^{1}$, Ozlem Canoz ${ }^{3}$, Hakan Gumus ${ }^{4}$, Mehmet Akif Ozdemir ${ }^{1}$, Huseyin Per ${ }^{4}$, Ekrem Unal ${ }^{1,5}$}

${ }^{1}$ Erciyes University, Faculty of Medicine, Department of Pediatrics, Division of Pediatric Hematology Oncology, Kayseri, Turkey

${ }^{2}$ Erciyes University, Faculty of Medicine, Department of Radiology, Division of Pediatric Radiology, Kayseri, Turkey

${ }^{3}$ Erciyes University, Faculty of Medicine, Department of Pathology, Kayseri, Turkey

${ }^{4}$ Erciyes University, Faculty of Medicine, Department of Pediatrics, Division of Pediatric Neurology, Kayseri, Turkey

${ }^{5}$ Erciyes University, Department of Molecular Biology and Genetic Department, Gevher Nesibe Genome and Stem Cell Institution, Genome and Stem Cell Center (GENKOK), Kayseri, Turkey

\begin{abstract}
Gliomatosis cerebri (GC) is a diffuse glial tumor of the brain which infiltrates more than two cerebral lobes; and generally seen in adults. Here we present a teenager boy who is diagnosed with gliomatosis cerebri. A 13-years old boy suffered from altered mental status and headache. Cranial edema and herniation was seen at cranial computerized tomography. Magnetic resonance image findings showed left dominance bilateral changes. Pathologic analysis of brain biopsy was relevant with gliomatosis cerebri. We would like to emphasize that gliomatosis cerebri should be considered in the differential diagnosis in patients who presented with abnormal neurological signs, and no clinical and laboratory evidence of infection, in the presence of diffuse brain involvement on the radiological imaging studies.
\end{abstract}

Key Words: Child, encephalitis, glial tumor, gliomatosis cerebri

Received: 01.12.2019

Accepted: 11.24 .2020

\section{ÖZET}

Gliomatozis serebri, ikiden fazla beyin lobuna görülen yaygın bir glial tümürüdür; ve genellikle yetişkinlerde görülür. Bu makalede gliomatozis serebri, tanısı konan ergen erkek çocuğu bildirmek istedik. Onüç yaşında erkek hasta mental değişiklik ve baş ağrısı yakınmaları ile başvurdu. Bilgisayarlı tomografide beyin ödemi ve herniasyon izlendi. Manyetik rezonans görüntülerde solda daha fazla olmak üzere bilateral değişiklikler görüldü. Beyin biyopsisinin patolojik incelemesi gliomatozis serebri ile uyumlu bulundu. Enfeksiyon bulgusu olmaksızın anormal nörolojik bulgular ile başvuran klinik ve laboratuvarda herhangi enfeksiyon kanıt bulunmayan ancak görüntüleme çalışmalarında yaygın beyin tutulumu olan hastaların ayırıcı tanııında gliomatozis serebri düşünülmesi gerekir.

Anahtar Sözcükler: Çocuk, Ensefalit, glial tümör, gliomatosis serebri

Geliş Tarihi: 12.01.2019

Kabul Tarihi: 24.11.2020

ORCID IDs: B.I.0000-0003-3469-8040, U.G.0000-0001-8733-2718, A.0.0000-0002-6100-1205, E. Y.0000-0003-4802-0986,F.T.M.0000-0003-4593-8679,0.C.0000-0002-02006970,H.G.0000-0001-5896-074X, M.A.0.0000-0003-0464-331, H.P.0000-0001-9904-6479, E.U.0000-0002-2691-4826

Address for Correspondence / Yazışma Adresi: Ekrem Unal, MD Departments of Pediatrics, Division of Pediatric Hematology, Oncology \& HSCT unit, and Molecular Biology and Genetic Department, Gevher Nesibe Genom and Stem Cell Institution, Genome and Stem Cell Center (GENKOK), 38010, Erciyes University, Melikgazi, Kayseri, Turkey Email: ekremunal@erciyes.edu.tr

CTTelif Hakkı 2020 Gazi Üniversitesi Tıp Fakültesi - Makale metnine http://medicaljournal.gazi.edu.tr/ web adresinden ulaşılabilir.

(C) Copyright 2020 by Gazi University Medical Faculty - Available on-line at web site http://medicaljournal.gazi.edu.tr/

doi:http://dx.doi.org/10.12996/gmj.2020.168 


\section{INTRODUCTION}

Brain tumors are the most common solid cancer in childhood (1). General encountered symptoms of brain tumors are headache, seizure, focal neurological abnormality; on the other hand rare clinical manifestations such as cardiac dysrhytms, and torticollis should me kept in mind (2,3). Moreover different diseases can mimic clinical and radiological features of brain tumors $(4,5)$. Gliomatosis cerebri $(\mathrm{GC})$ is a rare diffuse glial tumor of brain that can occur in adults; but extremely rare in pediatric period (6). GC can be presented like infectious, vasculopathic, and auto-immune diseases of central nervous system $(7,8)$. In this report we present a case of GC diagnosed by brain biopsy who presented with encephalitis-like symptoms.

\section{CASE REPORT}

A previously healthy 13-years-old boy was refereed to our hospital due to a diagnosis of midline shift. From his medical history, it was learned that he had admitted to a hospital with fever, headache, vomiting, and altered mental status. Treatment consisting vancomycin, ceftriaxone, and acyclovir was started because of suspected meningitis and/or acute encephalitis. On the third day of admission cranial computed tomography was performed because of the development of right facial paralysis, right hemi-paralysis and anisocoria. Preoperative brain computerized tomography (CT) scan demonstrates diffuse hypodensity in the left cerebral white matter with obliteration of the left lateral ventricle and midline shift to the right hemisphere (fig.1). The patient was admitted to the pediatric intensive care unit with the diagnoses of meningitis, and/or encephalitis. Temporoparietal bone decompression operation was performed because of diffuse cranial edema. Cranial magnetic resonance imaging (MRI) showed diffuse involvement of the left cerebral hemisphere with extension to the right hemisphere and mild midline shift (fig. 2). He was treated with intravenous immunoglobulin, and pulse methyl-prednisolone because of suspected encephalomyelitis. Plasma exchange was done because no clinical improvement was observed after intravenous immunoglobulin, and pulse methyl-prednisolone. The symptoms of encephalitis were worsened after plasma exchange; so stereotactic brain biopsy performed. Pathologic analysis of the biopsy was consistent with WHO grade 2 astrocytoma originated from GC. Radiation therapy combined with temozolomide was planned but he couldn't take chemotherapy because of increase of liver function tests. After the end of radiation therapy, the mental status, speaking and motor functions of the patent were rapidly improved. The parents refused further treatment after completion of the radiation therapy. It was learned that he is still alive in the $5^{\text {th }}$ year of diagnosis.

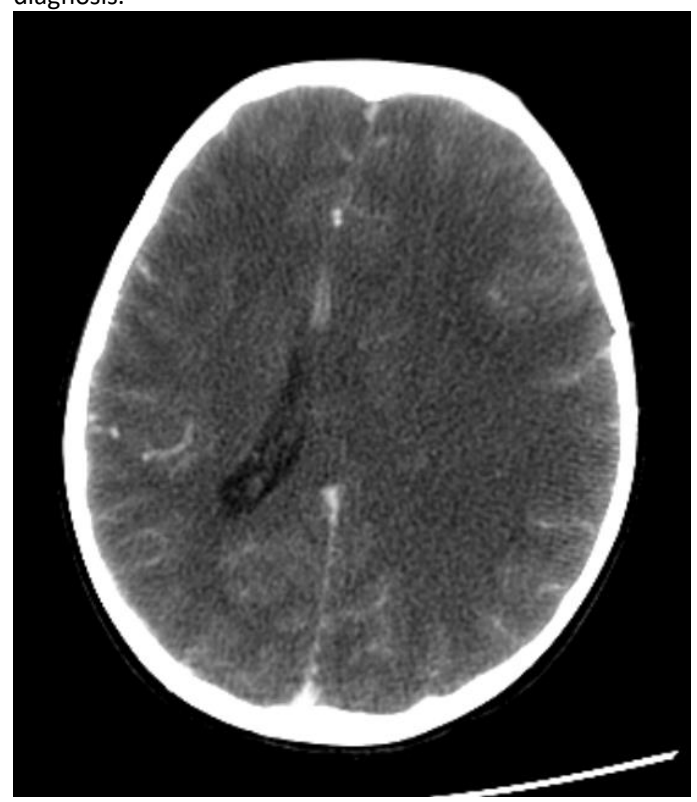

Figure 1. Preoperative brain CT scan demonstrates diffuse hypodensity in the left cerebral white matter with obliteration of the left lateral ventricle and midline shift to the right hemisphere.

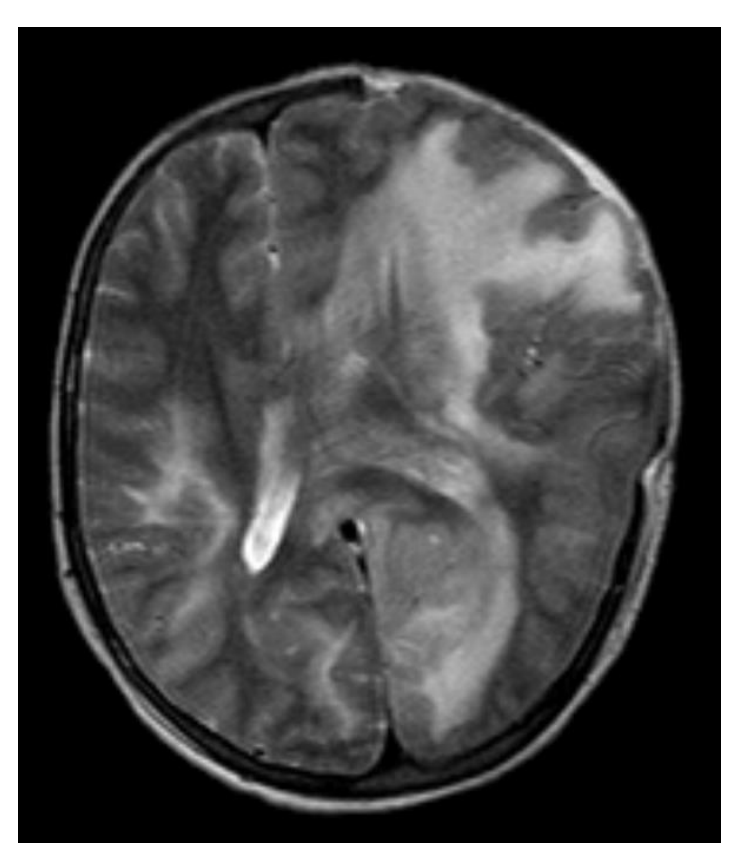

Figure 2. Axial T2-weighted image reveals diffuse involvement of the left cerebral hemisphere with extension to the right hemisphere via corpus callosum. Mild midline shift was demonstrated.

\section{DISCUSSION}

Gliomatosis cerebri is defined as a diffuse glial tumor that infiltrates bilateral hemispheres and deep gray matter and generally extend into the infratentorial compartment (6-13). GC is a glial tumor originated from astrocytes. From the study performed by the evaluation of the data from the Surveillance, Epidemiology and End, Results (SEER) database from1973 to 2012 reported 176 cases, only 15 patients (8.5\%) were under the 15 years old (14). The clinical presentations of GC have wide spectrum of different symptoms depending upon the involved neurological structures. The initial symptoms can range from a single seizure to status epilepticus. It was also reported that Patients may also present with neurocognitive alteration with poor academic performance and may even mimic dementia; personality and behavioral changes have also been observed. These unspecified signs and symptoms can cause diagnostic problems to the unexperienced physicians. The patients with GC generally have been previously labeled with other diagnoses and received treatments prior to the correct diagnosis. Among these, viral encephalitis and acute disseminated encephalomyelitis, multiple sclerosis, leukodystrophies, vasculitis were the most reported ones (6-14,15). Diagnosis of GC is confirmed by cranial imaging findings; and histopathological findings of brain biopsy. The brain biopsy is usually considered as an invasive procedure in clinical practice, which bury the underlying the true diagnosis in the clouds of confusions. The characteristic hallmarks of the lesions on MRI are hypointesity in T1 weighted sequences and hyperintensity in T2 weighted sequences and flair. Especially T2 weighted images are now considered the gold standard imaging technique $(6,16,17)$.

Although using radiation treatment and different chemotherapy regimens prognosis is poor. Time from the onset of symptoms to death can vary from weeks to years. It is difficult to determine the best treatment modalities because of the majority of patients diagnosed after the post-mortem investigations. Role of surgery is only limited to the biopsy like our patient. First choose in chemotherapy is an alkalization agent of temozolomide (13). However, temozolomide could not be used due to the hepatotoxicity in the current reported patient.

Armstrong et al. (9). published the one of largest series of children with GC in the literature with 13 patients during a period of 20 years; the median age ate the time of diagnosis was 12 years old. Despite the radiation therapy and various chemotherapeutic regimens, the prognosis is still poor. The contrast enhancement on MRI, and age $<10$ years were reported as a risk factors for children with GC. The mean survival time was 27 months after diagnosis and no patients live more than 6 years (9). 
Georgakis et al. (10) showed that the data from 523 published cases with GC. They have underlined that the clinical, imaging, and molecular outcome predictors that are similar to other gliomas. It is also reported that chemotherapy, and surgical resection, when feasible have beneficial effect on the outcomes of the patients with GC.

In conclusion, the misdiagnosis of GC may lead to delays in the optimal treatments related with many morbidity and mortality in patients. Therefore, GC should be considered in the differential diagnosis in patients who presented with abnormal neurological manifestations, and no clinical and laboratory evidence of infection, in the presence of diffuse brain involvement on the radiological imaging studies.

\section{Conflict of interest}

No conflict of interest was declared by the authors.

\section{Acknowledgment}

The authors thank Abdulhakim Coskun for critical review of this manuscript.

\section{REFERENCES}

1. Tumturk A, Ozdemir MA, Per $\mathrm{H}$, et al. Pediatric central nervous system tumors in the first 3 years of life: pre-operative mean platelet volume, neutrophil/lymphocyte count ratio, and white blood cell count correlate with the presence of a central nervous system tumor. Childs Nerv Syst. 2017;33:233-238 2. Sezer S, Baykan A, Yilmaz E, et al. Atrial fibrillation as an uncommon presentation in a large pleomorphic xanthoastrocytoma. Childs Nerv Syst. 2012; 28:475-479

3. Tumturk A, Kaya Ozcora G, Kacar Bayram A, et al. Torticollis in children: an alert symptom not to be turned away. Childs Nerv Syst. 2015; 31:1461-1470

4. Patiroglu T, Unal E, Yikilmaz A, Koker MY, Ozturk MK. Atypical presentation of chronic granulomatous disease in an adolescent boy with frontal lobe located Aspergillus abscess mimicking intracranial tumor. Childs Nerv Syst. 2010;26:149154.
5. Koksal V, Ekici MA, Menkü A, Bulut T, Öktem IS. Two Multiple Sclerosis Cases Confused with Cerebral Tumor. Erciyes Med J. 2008;30:116-118.

6. Greenfield JP, Castañeda Heredia A, George E, Kieran MW, Morales La Madrid A. Gliomatosis cerebri: A consensus summary report from the First International Gliomatosis cerebri Group Meeting, March 26-27, 2015, Paris, France. Pediatr Blood Cancer. 2016;63:2072-2077.

7. Jayawant S, Neale J, Stoodley N, et al. Gliomatosis cerebri in a 10 -year-old girl masquerading as diffuse encephalomyelitis and spinal cord tumour. Dev Med Child Neurol. 2001; 43:124-6

8. Richard HT, Harrison JF, Abel TW, et al. Pediatric gliomatosis cerebri mimicking acute disseminated

encephalomyelitis. Pediatrics. 2010; 126:479-482

9. Armstrong GT, Phillips PC, Rorke-Adams LB, et al. Gliomatosis cerebri: 20 years of experience at the Children's Hospital of Philadelphia. Cancer. 2006; 107:15971606

10. Georgakis MK, Tsivgoulis G, Spinos D, Liaskas A, Herrlinger U, Petridou ET. Prognostic Factors and Survival of Gliomatosis Cerebri: A Systematic Review and Meta-Analysis. World Neurosurg. 2018;120:e818-e854.

11. Ranjan S, Warren KE. Gliomatosis Cerebri: Current Understanding and Controversies. Front Oncol. 2017;7:165. doi: 10.3389/fonc.2017.00165.

12. Landi A, Piccirilli M, Mancarella $C$, et al. Gliomatosis cerebri in young patients' report of three cases and review of the literature. Childs Nerv Syst. 2011;27:1925.

13. Lee $Y A$, Kupsky $W$, Altinok $D$, et al. Gliomatosis cerebri in a 12-year-old patient. 176 Pediatr Neurol. 2015; 52:462-463.

14. Georgakis MK, Spinos D, Pourtsidis A, Psyrri A, Panourias IG, Sgouros S, Petridou ET. Incidence and survival of gliomatosis cerebri: a population-based cancer registration study. J Neurooncol.

2018;138:341-349

15. Lodi R, Setola E, Tonon C, et al. Gliomatosis cerebri: clinical, neurochemical and neuroradiological response to temozolomide administration. Magn Reson Imaging. 2003;21:1003-1007.

16. Peretti-Viton $\mathrm{P}$, Brunel $\mathrm{H}$, Chinot $\mathrm{O}$, et al. Histological and MR correlations in Gliomatosis cerebri. J Neurooncol. 2002;59:249-259.

17. Uysal $E$, Erturk $M$, Yildirim $H$, et al. Multivoxel magnetic resonance spectroscopy in gliomatosis cerebri. Acta Radiol. 2005;46:621-624. 